\title{
Cost comparison studies: Their value, validity and future from an international perspective
}

\begin{abstract}
Bjöern P. Jacobsen
Physical, economic, social, political or cultural factors are commonly defined as factors businesses consider when selecting a new site to locate. This paper examines which selection factors are considered important by potential investors and their advisors by analyzing the value of international cost comparison studies, specifically looking at costrelated site selection factors. This research analyses the site selection process on an international level and concludes that sponsorship is an influencing factor. The author argues that locations that do not have the ability to financial contribute to the development of the cost comparison study are at an unfair advantage.
\end{abstract}

Keywords: site selection, sponsorship, location decision

Site selection processes have been the subject of economic research for nearly two centuries. Taking the current impact of globalization into account, it is obvious that the traditional view of industrial location theory needs to be revised. Costs are no longer the major concern in industrial location theory.

Decision making processes have long been high on the priority list of economic development specialists. Place marketing specialists state that these decisions are "not unlike the selection of the pope or the next site for the summer Olympics" (Kotler, 1999). However, the majority of companies do not operate their own site selection departments or have permanent teams which have a specific knowledge about location theories and their practical application. Consequently a wide range of practical approaches exist, with the least scientific being the method known as the 'doctrine of social proof'. This doctrine believes that location decisions are "often based on others having previously made a similar decision" (Adkison, 2001). It is presumed that the others did take the right decision in choosing the specific location.

A poll (Levine, 1997) of 1,000 North American companies revealed that the doctrine of social proof is spread wider than experts often believe: corporate executives stated that their prime source for site selection information is 'corporate grapevine (informal information) followed by news stories and corporate travel.' The information generated through this approach is "why others have already selected the site, not why you should". A perfect example of social proof.

A more structured approach to site selection is a step-by-step approach, following the principle of complexity reduction. The optimal location is found by elimination using macro-, meso- and 
micro-specific pre-selections. However, it must be noted that this approach can often only be applied by larger corporations as it requires considerable resources to carry out a broader location process.

Since small to medium sized enterprise often lack the time and resources for an in-depth comparison of possible sites, they usually follow the principle of reducing the research efforts. A recent German study (Forschungsstelle, 2002) of location decisions revealed that none of the companies involved in the study had evaluated more than six locations. On average only 2.1 locations were evaluated.

From an industry-specific study (European Business School, 2001) similar conclusions could be drawn: out of 8,989 e-commerce companies interviewed only 11.7 per cent did a systematic location research including an analysis of site selection factors. Another 12.1 per cent of the companies discussed alternative locations without an assessment of specific site selection factors. The remaining 76.2 per cent of the companies interviewed did not even consider alternative locations when setting-up their new operations.

These data indicate that location decision-makers employ a wide range of approaches: from totally unstructured 'research' to more systematic projects, often assisted by professional site selection consultants. It is estimated that only around 30 per cent of site location projects in the United States use the services of specialized site selection firms (Pittman, 2001).

The question of costs is an important issue in the practical site selection process. This is evident as "new industry clusters have often developed in lower cost periphery regions" (Vause, 1999). This development was supported by a reduction in trade barriers and transport costs. At this point, theory and practical application merge as today's "location decisions are driven by considerations of access to markets on the one hand and by production costs on the other" (Vause, 1999). It is therefore worthwhile taking a closer look at the cost side, while bearing in mind that other aspects, such as demand for the product and adequate market access, are equally important.

\section{Site selection factors}

Physical, economic, social, political or cultural factors, possibly influencing the development of a company in a positive or negative way, are commonly defined as location or site selection factors. In the context of this paper it is of interest which site selection factors are considered important by potential investors and their advisors. When analyzing the value of international cost comparison studies it is of special interest which (if any) cost-related site selection factors are regarded as relevant by companies evaluating locations for investment. 
The importance of site selection factors can be evaluated from different point of views. A high level classification differentiates between general site selection factors and industry-specific site selection factors. General site selection factors should be valid for companies regardless of their main area of activity. Extensive research into the importance of these factors has been carried out over the years, and will have to be carried out in the future, as the importance of site selection factors is changing constantly.

This is best illustrated by the current transformation from industrial nations to service-oriented economies putting such site selection factors as telecommunication and traffic infrastructure higher on the agenda of international site seekers. Moreover so called soft factors, such as quality of life or the availability of skilled labor, seem to become more important while the hard facts such as costs (in general) may be losing their predominant role.

In order to evaluate the importance of general site selection factors on an international level a total of 21 different sources (nine originating in North America, 12 originating in Europe) dealing with site selection factors have been analyzed. They cover a time period of 17 years (1986 - 2002), include two continents (North America and Europe) and distinguish between 147 individual site selection factors:

Table 1: Sources of general site selection factors (order of publication date)

\begin{tabular}{|l|l|l|}
\hline Source & $\begin{array}{l}\text { Year of } \\
\text { Study }\end{array}$ & $\begin{array}{l}\text { Geographic } \\
\text { Focus }\end{array}$ \\
\hline Area Development Magazine - Annual Corporate Survey & 1986 & USA \\
\hline Area Development Magazine - Annual Corporate Survey & 1990 & USA \\
\hline Jones Lang Wotton - Immobilienstudie für Wien & 1991 & $\begin{array}{l}\text { Austria } \\
\text { (Vienna) }\end{array}$ \\
\hline $\begin{array}{l}\text { Pausenberger - Die Standortpolitik internationaler } \\
\text { Unternehmen }\end{array}$ & 1994 & International \\
\hline Area Development Magazine - Annual Corporate Survey & 1995 & USA \\
\hline $\begin{array}{l}\text { DIFU - Rangfolge der wichtigsten Standortfaktoren bei } \\
\text { unternehmensorientierten Dienst-leistungen }\end{array}$ & 1995 & Germany \\
\hline $\begin{array}{l}\text { DIW - Wie die ostdeutsche Industrie ihre } \\
\text { Standortbedingungen sieht }\end{array}$ & 1995 & Germany (East) \\
\hline Fischer - Site Location Considerations & 1995 & International \\
\hline Hahne - Regionale Wirtschaftsförderung in der Praxis & 1995 & Germany \\
\hline $\begin{array}{l}\text { Krieger/v. Stackelberg - Standortwahlentscheidungen und } \\
\text { Transportpreise in Fertigungs-betrieben peripherer } \\
\text { Regionen }\end{array}$ & 1995 & $\begin{array}{l}\text { Germany } \\
\text { (North) }\end{array}$ \\
\hline Standortgutachten Herne: Standortfaktoren und & 1995 & Germany \\
\hline
\end{tabular}




\begin{tabular}{|l|l|l|}
\hline Standortqualität in Herne & & (Herne) \\
\hline Tillet - Real Site Location Considerations & 1995 & International \\
\hline Balderjahn - Studie: Wirtschaftsstandort Brandenburg & 1996 & $\begin{array}{l}\text { Germany } \\
\text { (Brandenburg) }\end{array}$ \\
\hline DFAIT - European Investor Survey & 1998 & Europe \\
\hline Area Development Magazine - Annual Corporate Survey & 1999 & USA \\
\hline Kotler - Marketing Places Europe & 1999 & Europe \\
\hline KPMG - Competitive Alternatives & 1999 & International \\
\hline Area Development Magazine - Annual Corporate Survey & 2000 & USA \\
\hline DIW - Standortbedingungen in Ostdeutschland verbessert & 2000 & Germany (East) \\
\hline KPMG - Competitive Alternatives & 2001 & International \\
\hline $\begin{array}{l}\text { Vitols - Unternehmensführung und Arbeitsbeziehungen in } \\
\text { deutschen Tochter-gesellschaften großer ausländischer } \\
\text { Unternehmen }\end{array}$ & 2001 & Germany \\
\hline
\end{tabular}

The results from these studies have been made comparable by calculating the importance of the individual site selection factors (as rated by the demand side) on a scale between 0 (= unimportant) to 100 (= most important). Following this calculation, the site selection factors have been classified into two main categories (business-related factors and personal-related factors) with three sub-categories (direct cost factor, indirect cost factor, non-cost factor) each.

Business-related site selection factors influence the cost of doing business of a company while personal-related factors influence the cost of living by the individual employee. Direct cost factors have an immediate effect either on the cost of doing business or the cost of living; examples include labor costs or private housing costs. Indirect cost factors have an indirect effect on the cost of doing business or the cost of living; examples include the proximity to customers (which has an influence on the transportation costs) or commuting times (which have an influence on the commuting costs). Non-cost site selection criteria are factors where a direct or indirect influence on the cost of doing business or cost of living cannot be calculated; examples are the quality of support offered by economic development agencies or the cultural environment. On a higher aggregation level, direct cost factors could be described as objective, while non-cost factors might be described as subjective, in terms of rating by site seekers.

The following figure gives an overview of the general site selection factors, their importance rating and their cost relevance. 
Figure 1. General site selection factories: Importance and cost relevance

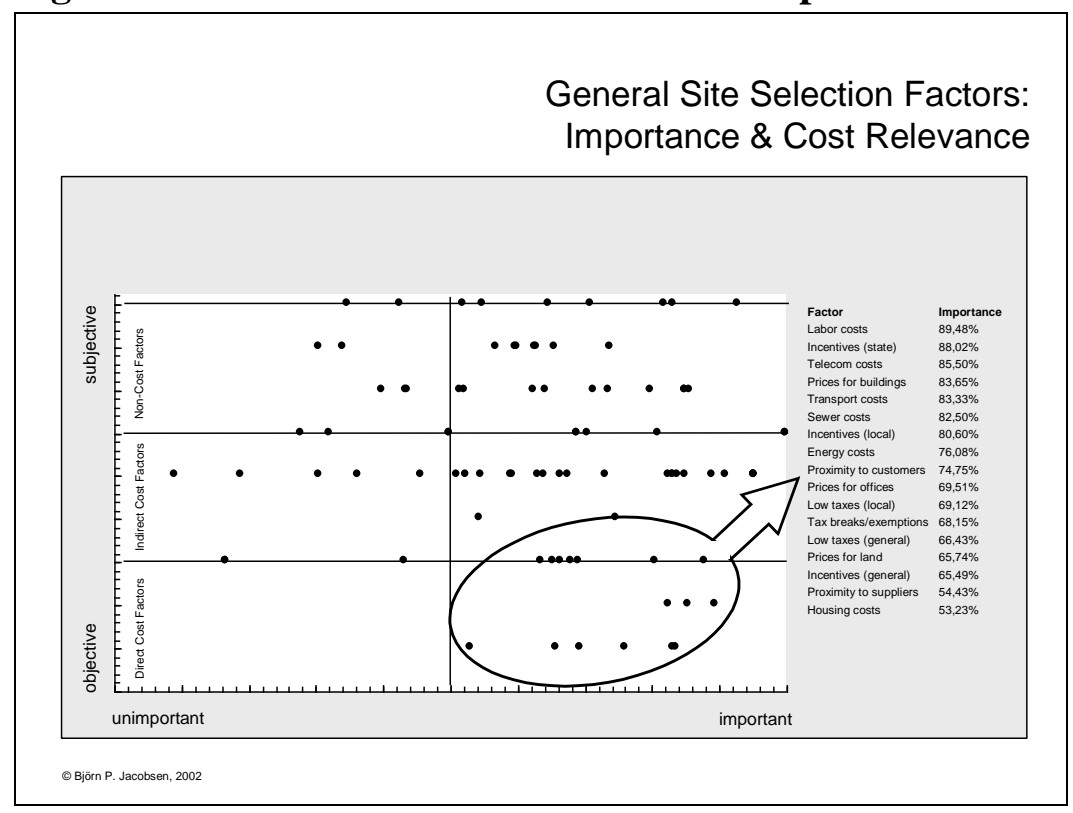

Out of the 147 general site selection factors analyzed, 17 are direct cost factors or indirect cost factors with an importance rating of 50 per cent or more and a high objectivity. In other words, more than 11 per cent of general site selection factors have a direct impact on the cost of doing business or cost of living, while being rated important by the site seekers. Out of the 17 direct and indirect cost factors rated important, 16 are business related cost factors and only one (housing costs) is a personal related cost factor. The factors are listed in order of their importance rating (Figure 1 - right-hand section).

An additional approach to rate the value of cost-related site selection factors to site seekers is to measure how often individual site selection factors have been mentioned (irrespective of their importance rating) in the 21 studies taken into consideration for this research. A site selection factor might receive a high importance rating (as illustrated in Figure 1) but might only be mentioned in a limited number of studies, leaving limited evidence as to the importance rating. The following figure lists general site selection factors which have been mentioned in more than three of the 21 studies examined. The direct and indirect cost factors, with an importance rating of 50 per cent or more, have been highlighted for better identification. 
Figure 2. General site selection factors: Frequency of studies paying attention to the factor

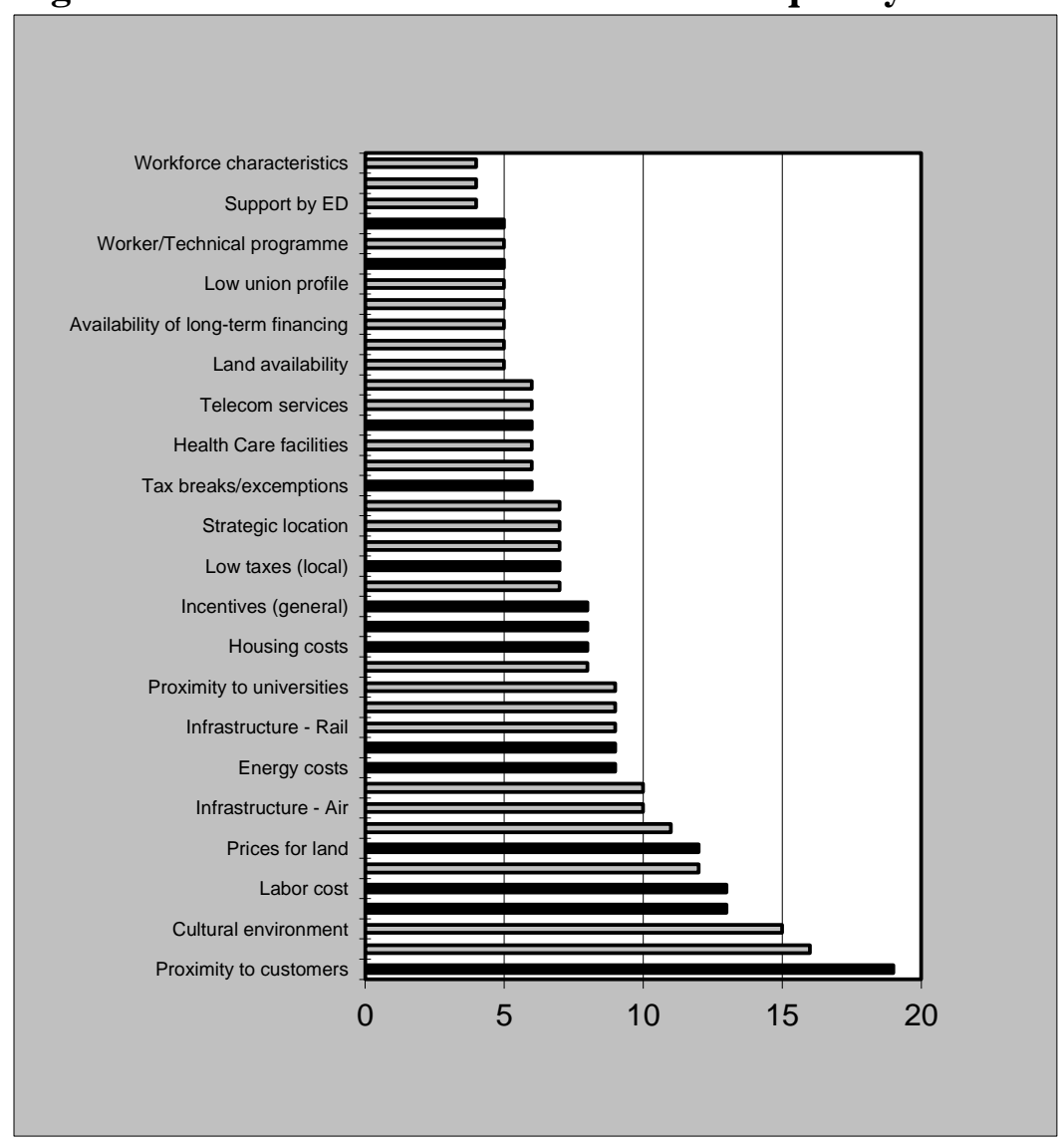

Considering both Figure 1 and Figure 2 it becomes obvious that three cost-related site selection factors with a high importance rating might be considered less valuable to site seekers, as they have been mentioned in less than four out of 21 studies analyzed. The following table will, therefore, neglect telecom costs, transport costs and sewer costs as only few studies considered these factors at all. The table is a synopsis between Figure 1 and Figure 2 listing general site selection factors which have a direct or indirect impact on cost of doing business or cost of living, show an importance rating of more than 50 per cent ( 75 per cent for indirect cost factors) and are frequently (more than three times out of 21 possible) mentioned in relevant studies.

Table 2. Priorities of cost-related (general) site selection factors

\begin{tabular}{|l|l|l|l|l|l|} 
Site Selection & $\begin{array}{l}\text { Importanc } \\
\text { Factor }\end{array}$ & $\begin{array}{l}\text { Importa } \\
\text { e Rating } \\
\text { nce } \\
\text { Priority }\end{array}$ & $\begin{array}{l}\text { Freque } \\
\text { ncy }\end{array}$ & $\begin{array}{l}\text { Freque } \\
\text { ncy } \\
\text { Priority }\end{array}$ & $\begin{array}{l}\text { OVERALL } \\
\text { PRIORITY }\end{array}$ \\
\hline Energy costs & $76,08 \%$ & 5 & 9 & 4 & 4 \\
\hline Housing costs & $53,23 \%$ & 14 & 8 & 5 & 12 \\
\hline Incentives (general) & $65,49 \%$ & 12 & 8 & 5 & 10 \\
\hline Incentives (local) & $80,60 \%$ & 4 & 6 & 7 & 6 \\
\hline Incentives (state) & $88,02 \%$ & 2 & 5 & 8 & 5 \\
\hline
\end{tabular}




\begin{tabular}{|l|l|l|l|l|l|}
\hline Labor costs & $89,48 \%$ & 1 & 13 & 2 & 1 \\
\hline Low taxes (general) & $66,43 \%$ & 10 & 5 & 8 & 11 \\
\hline Low taxes (local) & $69,12 \%$ & 8 & 7 & 6 & 7 \\
\hline Prices for buildings & $83,65 \%$ & 3 & 8 & 5 & 3 \\
\hline Prices for land & $65,74 \%$ & 11 & 12 & 3 & 7 \\
\hline Prices for offices & $69,51 \%$ & 7 & 9 & 4 & 6 \\
\hline Proximity to customers & $74,75 \%$ & 6 & 19 & 1 & 2 \\
\hline Proximity to suppliers & $54,43 \%$ & 13 & 13 & 2 & 8 \\
\hline Tax breaks/ exemptions & $68,15 \%$ & 9 & 6 & 7 & 9 \\
\hline
\end{tabular}

The last column of Table 2 highlights the overall priority of cost-related site selection factors from an international perspective. The overall priority is calculated from the importance priority (50 per cent) and frequency priority (50 per cent) which results in a fairly accurate picture of the situation: labor costs, proximity to customers, prices for buildings, energy costs and state incentives are the top five cost-related site selection factors from an international perspective.

As this research has an international scope, it is of interest whether the priority (in terms of importance and frequency), of the direct and indirect cost factors presented in Table 2 is the same in the geographic areas (defined as continents) investigated or whether a specific pattern can be identified. A total of 14 cost-related site selection factors have been scrutinized from a geographic point of view; three factors (incentives - general, incentives - state, low taxes - local) had to be neglected as their frequency for one of the geographic areas was too low (one or less) leaving 11 factors for the analysis. The following figure compares the overall priority of costrelated site selection factors with the priority rating of studies in North America and Europe. 
Figure 3. General site selection factors: Geographical priorities

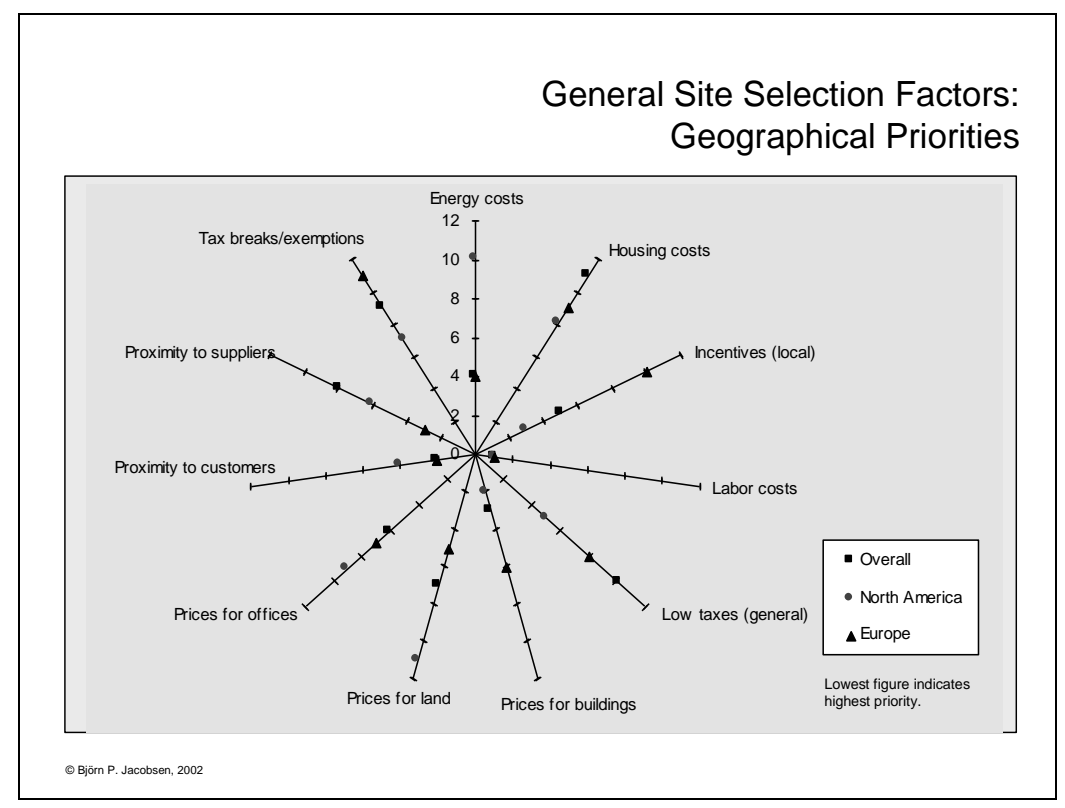

From Figure 3, four basic 'patterns' can be identified. The first pattern consists of site selection factors with a high priority in Europe and a low priority in North America. Energy costs are an example reflecting the relatively lower costs of energy in North America compared to Europe. Prices for land and prices for offices (rent) are another example based on the generally lower cost of real estate in North America in comparison to Europe.

The second pattern consists of factors with a high priority in North America and a low priority in Europe. Typical examples in this category are tax breaks/exemptions and incentives which are both much higher on the agenda in North America than in Europe. An explanation might be that these factors are not available in Europe respectively and are handled in a much more restricted way due to the control of the European Commission.

The third pattern includes factors with a high priority in North America and an overall lower priority. Examples are housing costs and low taxes. In Europe emphasis is put on harmonizing the tax systems within the European Union; although this is a long-term goal it might be a reason that tax competition is more restricted, especially at the local level.

The fourth pattern is not actually a pattern but rather a collection of individual factors. Labor costs are included in this category, being the number one priority both in North America as well as in Europe. In general, it could be said that priority classification seems to be based more on home-grown experience rather than facts. A North American investor seeking a suitable site in Europe would, for example, give priority to tax exemptions which are not commonly used in Europe. 
Apart from the geographic point of view, it is of interest how valuable site seekers consider costrelated site selection factors over time. The sources considered for this research therefore cover a period of 17 years.

After having analyzed the 14 cost-related site selection factors in terms of importance shift over time, no specific overall pattern could be identified. In any event, Area Development Magazine (Gambale, 2000) is carrying out an annual survey of general site selection factors in North America. Although the survey design has been slightly modified within the last 17 years, a comparison of the survey results offers a good indication of the importance shift, at least on the North American market.

Figure 4. General site selection factors: Importance shift over time

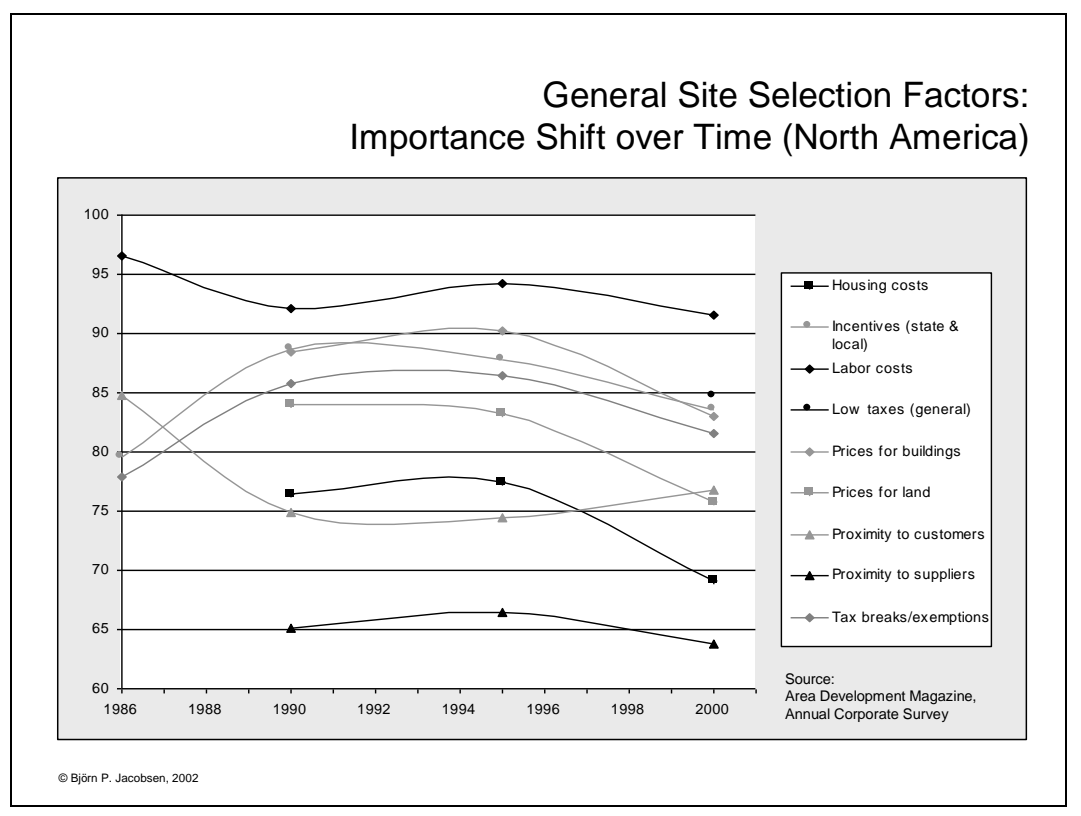

Two exceptions can be found: first, the importance of labor costs seems to be more sensitive to short-term fluctuations. Second, the proximity-to-customer-factor is showing a different development as far as the importance rating is concerned. While the proximity to customers seemed to be a much lower priority (in fact a decreasing importance) in the mid-nineties it accelerated in importance. This might be explained by the higher influence of service industries on the survey sample, as service-oriented businesses generally seek a much closer relationship with their customers than traditional production industries do. It is interesting to note, that at the same time, indirect cost-related site selection factors such as labor availability and infrastructure have increased in importance.

After having looked solely at the demand site (= site seekers), it is finally of interest to analyze whether the suppliers (= communities and their respective economic development departments) 
agree with the priorities presented in Table 2. A comparison between the demand and supply side reveals whether the requirements communicated by the site selection community are understood by the economic developers.

Unfortunately only very few studies concerning the general site selection factor priorities set by communities have be published so far. Again reliable data is only available for the North American market (Musil, 2001). Out of the 17 general site selection factors considered very important in that study only four can be considered as cost-related site selection factors. Cost of living is considered the number one cost-related site selection factor (priority 6 out of the 17 factors), proximity to customers is the second most important cost-related factor (priority 7 out of the 17 factors), cost of housing is the number three in terms of cost factors (priority 9 out of the 17 factors) and finally labor costs are number four (priority 14 out of the 17 factors).

The number one cost-related site selection factor in the supplier-driven study is not even part of the demand-driven priority list given in Table 2. The second most important cost factor of the supplier-study equals the assessment of the demand side: proximity to customers has the same priority for communities and site seekers. The number three cost-related site selection factor of the supplier side turns out to be the lowest priority site selection factor of the demand side: housing costs. Interestingly the cost-related site selection factor with the lowest priority on the community list is the highest on the site seekers list: labor costs. In general, there seems to be limited agreement on the priority of cost-related site selection factors the site seekers looking for the best match to their requirements.

To summarize, the importance of general site selection factors has been investigated so far with a number of studies carried out throughout the world. Nearly 150 general site selection factors can be identified on an international level, of which 17 are cost-related site selection factors with a high importance and objectivity rating. In other words: more than 11 per cent of the general site selection factors have an (direct or indirect) impact on the cost of doing business or the cost of living.

From an international perspective, the cost-related site selection factors with the highest priority are: labor costs, proximity to customers, prices for buildings, energy costs and incentives. It is important to note that North American and European site seekers do have different priority lists. While there is agreement on the priority of labor costs and proximity to customers, contradictory priority ratings are found for energy costs or local incentives. Economic developers, using costrelated site selection factors, need to be sensitive to these findings when setting-up their campaigns.

Even more important is the general decrease in importance of cost-related site selection factors within the last 17 years. Only labor costs and proximity to customers keep their high priority 
position within the site selection factor matrix, although their priority is valued differently by the supplier and demand side.

Direct cost factors are on the priority list of site seekers but their general importance on the final site selection should not be overestimated - or as one of the site selection firm states: "Those who position solely on property/land availability, cost and incentives will increasingly lose position.” (Ernst \& Young, 2001)

\section{Cost comparison studies}

The number of cost comparison studies available has significantly increased in recent years. While there is no standard definition of what a cost comparison study is, from a site seekers point of view at least three fundamentally different types of studies can be identified.

Studies of Competitiveness are frequently the least valuable instruments for corporate site seekers working on specific investment projects, as these studies tend to present indexes only identifying competitive rankings between nations. Moreover the data presented is mostly not separated by regions or cities, making this type of study a less valuable source of data for cost comparison studies. The study results are usually of indicative character for corporate site seekers only.

As part of this research paper, three strategies have been analysed including the well-known Global Competitiveness Report (World Economic Forum, 2001) and the World Competitiveness Yearbook (IMD, 2001). A major shortcoming in terms of value for cost comparison studies, is the unspecific approach in terms of target industries as well as the absence of quantifiable data. With the exception of the World Competitiveness Yearbook, little quantifiable data is presented in the studies.

A more improved version of the Studies of Competitiveness are the so-called Business Cost Collections. This type of study focuses on specific cost items and collects the cost data related to the items for the most important investment markets. These markets are defined either as nations, regions or even sub-regions. Care should be taken as cost comparisons calculated based on these cost collections do not reflect the overall cost position of doing business in that market. None of the business cost collections analysed contained sufficient data to enable a full cost comparison. Frequently-used business data collections are the Worldwide Business Cost Comparisons (Economist Intelligence Unit, 2002) or the Prices and Earnings Around the Globe (UBS, 2000). Out of the four business data collections, none covers the full range of cost data needed to conduct a comprehensive cost comparison study. Even more importantly, none of the studies contains industry-specific data enabling the data to be used for individual cost comparison studies. This makes business data collections of limited value to corporate site seekers. 
Cost Comparison Studies are the third type of studies to be analysed as part of this research paper. This type of study goes a step further by combining cost patterns and cost data for various industries thereby giving a fuller picture of the cost site.

Basically cost comparison studies consist of three parts. Part one contains the standard operating parameters for specific industries, from which the site seekers can select the industry which best matches the individual site selection project. Part two includes the cost data for various locations examined as part of the cost comparison. Within part three of the cost comparison study, the operating parameters are multiplied by the location-sensitive cost data. As a result, benchmarking between various locations for a specific type of industry can be carried out. Moreover, this type of study allows for a multi-period comparison. Although even cost comparison studies have shortcomings, they currently represent the most valuable tool out of the three study types presented.

Leading suppliers of cost comparison studies include KPMG, with the Competitive Alternative Series (KPMG, 1999a,b,c and 2001), and The Boyd Company, with a number of studies prepared for the Province of New Brunswick or the Sioux Falls Development Foundation. As part of this research, a total of 17 cost comparison studies have been analysed which show different quality levels. The common goal of all cost comparison studies is to give a full picture of the cost-related site selection factors creating a valuable tool for corporate site seekers.

\section{Inventory of costs comparison studies}

As outlined in the preceding section, cost comparison studies represent the only type of study fulfilling the basic requirements of corporate site seekers. A more detailed analysis will therefore concentrate on this type of study and will not consider both Studies of Competitiveness and Business Cost Collections.

Cost comparison studies have to meet a number of criteria in order to assist corporate site seekers with their individual feasibility studies. First of all the data needs to be up-to-date in order to draw a true picture of the cost situation. Out of the 17 cost comparison studies seven studies do not indicate when the data was collected, six presented data older than three years and only four studies contained data collected within the last three years. From a time perspective, only four out of the 17 studies can be considered sufficiently up-to-date.

Cost comparison studies are frequently valuable to international site selectors when they present detailed data geared towards the needs of the individual site selection project. To do so, cost comparison studies should include more than one country and show an industry-specific approach. The latter can be achieved by focusing the study on a specific business area or by including a number of specific business areas within one study. Two studies can not be 
considered international as they only include one country, 12 studies have a limited international focus as they include two countries only (Canada and the United States) while the remaining three studies have a truly international focus with some minor shortcomings in representing Asian country data. Interestingly only one study falls short of delivering industry-specific data with the remaining 16 cost comparison studies fulfilling this requirement.

A third area of interest is if the cost comparison studies cover at least the cost components considered important by the site selection community. Figure 1 presents the 'traditional' view of cost-related site selection factors considered important. Apart from these cost components it has been shown that exchange rates and purchasing power parities play an important role and should thus not be neglected in cost comparison studies. The following figure shows how well the 17 cost comparison studies meet these requirements:

Figure 5 confirms that nearly all cost comparison studies pay attention to energy costs, labor costs and total occupancy costs, while office costs and transportation costs are not examined in all studies. Even less frequently, attention is paid to taxes, land and building costs. Especially 'improved' cost items, such as the calculation of the total tax burden (taking both tax rates and tax bases into account) and unit labor costs (paying attention to productivity), are less frequently analysed in cost comparison studies, leaving considerable room for improvement.

Housing costs, an important cost-related site selection factor, is not mentioned at all. On one hand this is understandable as cost comparison studies focus on business costs; on the other hand an important cost factor is not dealt with.

Figure 5. Cost comparison studies and major cost components

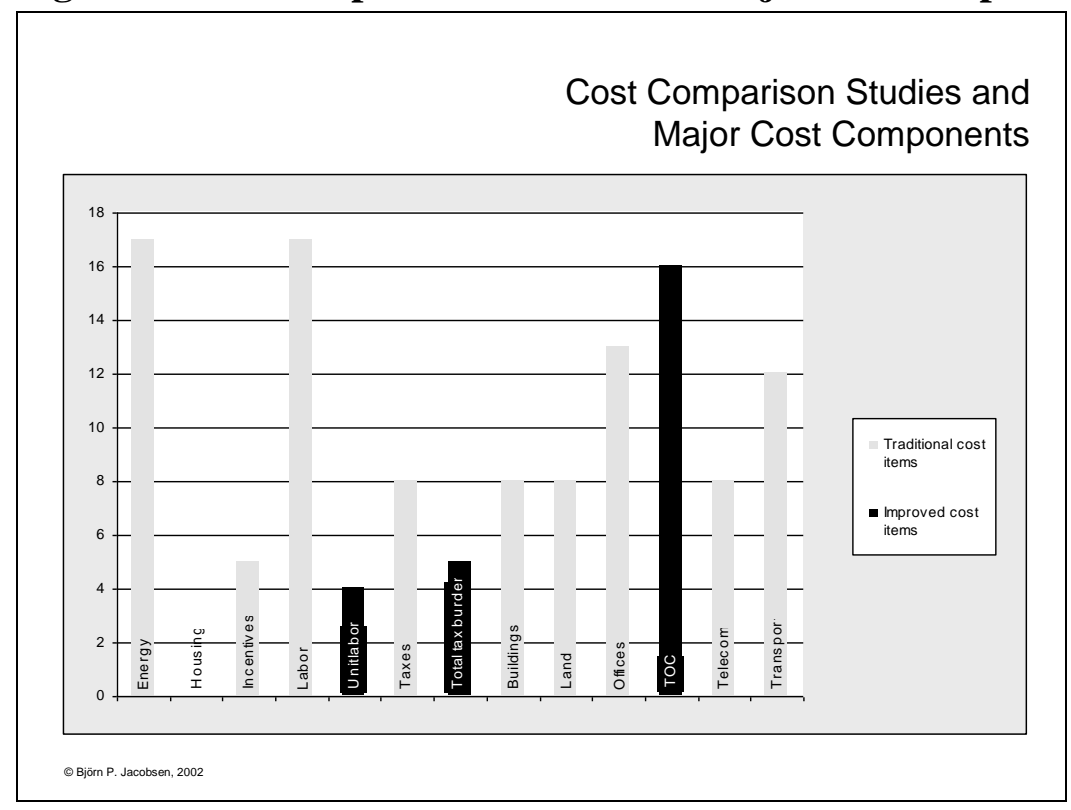


In summary, it could be said that a number of current cost comparison studies show shortcomings in terms of topicality, international focus and application of 'improved' cost items (e.g. unit labor costs instead of hourly labor costs). From the cost comparison studies analysed, only the KPMG study series meets the minimum requirements allowing for a true international cost comparison, although there are specific areas for improvement which would increase the validity of the data.

\section{Cost comparison studies as a marketing tool}

While considerable efforts are taken by economic development agencies and consultants to produce and market cost comparison studies as part of inward investment promotion campaigns, the value of such studies to the site selection community is largely unknown. In order to evaluate whether the resources spent on cost comparison studies is well invested, a survey was carried out among corporate site seekers.

Based on Ernst \& Young's European Investment Monitor (Ernst \& Young, 2001), the leading companies in terms of recent investment projects were identified. A total of 85 site selection executives from across Europe and North America were contacted in order to investigate the application rate of standardized cost comparison studies. A total of 12 questionnaires (= 14 per cent response rate) were returned, representing a total of 155 investment projects involving 49,500 jobs over a five-year period. The majority of the investment projects covered manufacturing and service industries, with the main geographic focus on Europe and North America.

The majority of the responding companies ( 75 per cent) perform project feasibility studies (including operating cost studies) in-house; some (50 per cent) with the assistance of external consultants. Interestingly, only 25 per cent of the companies use standard cost comparison studies as presented in the preceding section, with the remaining companies preferring raw data to be used with their own proprietary systems. Those using standard cost comparison studies rate their usefulness for specific site selection projects to be 'partly' useful.

As much emphasis of this research paper has been put in presenting valuable cost items it is of interest what sort of data is actually used by corporate site seekers. To answer this questions site selection executives were asked to give their preference for labor cost/hour versus unit labor cost, office cost/square feet versus total occupancy costs, tax rates versus total tax burden and telecom cost/minute versus total communication expenses. 75 per cent of the responding companies preferred labor cost/hour to unit labor cost, demonstrating a clear shortcoming in today's site selection processes; obviously productivity data do not make their way into site selection projects. This area offers considerable room for improvement. 50 per cent of the companies still use office costs/square feet (square meter) as opposed to total occupancy costs 
which is a better measure for the overall facility costs. Even more astonishing, 66 per cent of the companies rely on tax rates rather than the total tax burden which would include the tax base resulting in actual taxes to be paid. Finally slightly more than 50 per cent use telecom cost/minute as opposed to total telecommunication costs. In summary, these findings make clear that considerable efforts have to be put into future cost comparison studies to convince site seekers of the benefits total costs offer.

Finally, it was of interest to evaluate whether standard cost comparison studies are used 'standalone' or whether the results are weighted. Nearly 50 per cent of the companies use some form of cost-quality indexing, with other companies (25 per cent) using inhouse matrixes to weight the results from standard cost comparison studies.

\section{The validity of cost comparison studies}

In order to effectively employ these site selection factors in the process of identifying suitable sites, cost comparison studies have been introduced as a marketing tool by government agencies and specialized consulting companies. These cost comparison studies are generally a valuable tool, allowing the corporate site seeker to structure the complex process of calculating the cost of starting and operating a business at a given number of competing locations.

However, the cost comparison studies analyzed so far have some shortcomings which might put their results into question. While the value of cost comparison studies has been confirmed in principle, it is necessary to scrutinize selected cost comparison studies and the site selection factors involved in terms of validity of the results produced. To do so, four areas will be of special interest: the selection of comparable places, the selection of operating parameters, the 'time dimension' and the extent of the comparison. As an introduction, an analysis of the structure of cost comparison studies will be presented.

\section{The structure of cost comparison studies}

An analysis of the 17 cost comparison studies currently available reveals that they consist of three distinct parts. Part one is a description of the company by using standard operating parameters for labor, facilities, transportation, utilities, taxes and financing. Part two is a collection of location-sensitive business costs for a number of pre-selected locations. Part three presents the results by 'multiplying' the standard operating parameters with the locationsensitive costs. From the results a cost ranking of various locations for the industry chosen is developed. This approach frequently involves thousands of individual cost items - the more locations are chosen for comparison, the higher the number of individual cost items. 
The definition of the operating parameters is crucial for the outcome of the study. Cost comparison studies use average operating parameters for the industries analysed. Interestingly, none of the studies analysed as part of this research paper gives details on how these average operating parameters have been developed, thus putting their overall validity into question.

Figure 6. Structure of cost comparison studies

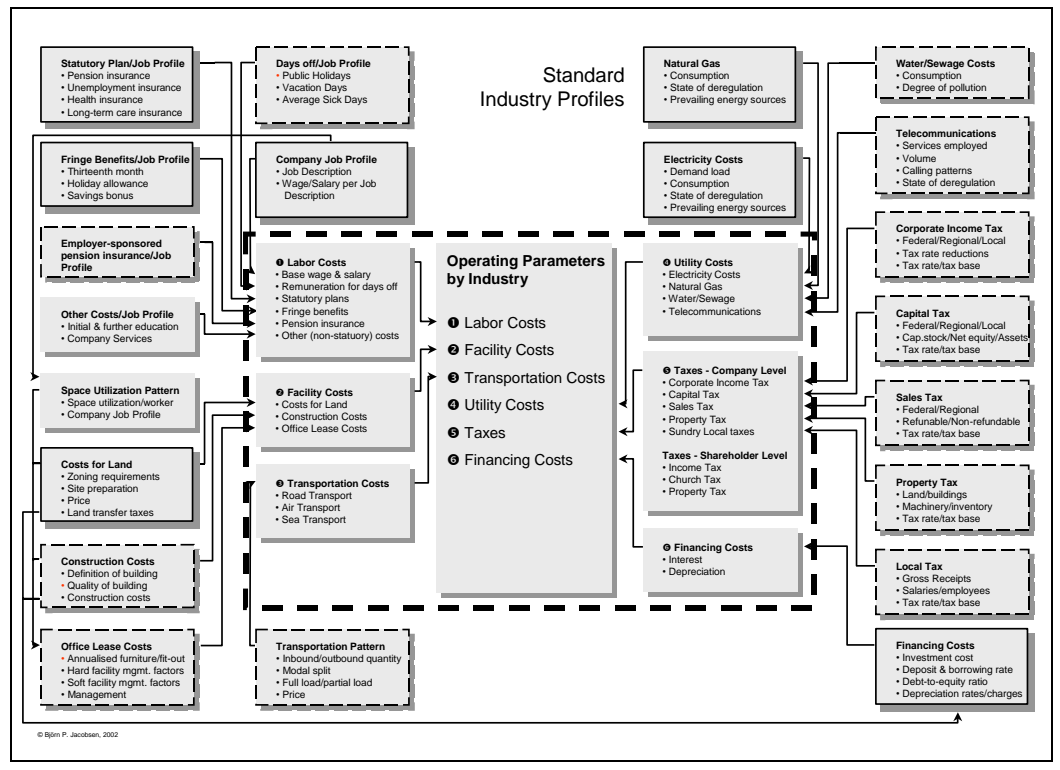

When designing the standard operating parameters, emphasis is put on the location-sensitive data neglecting standard cost items such as machinery investments which are considered equal in developed countries. None of the standard cost comparison studies covers all aspects of the model, but certain groups and sub-groups are part of all studies examined. This includes seven out of 21 sub-groups (highlighted with a bold frame). An additional 12 sub-groups are found in some of the studies analysed (marked with a dotted frame). Also sub-groups which are represented in all studies but not to their whole extent are marked with a dotted frame:

The quality of building factor is part of the sub-group construction costs. Its value varies from country to country based on the national building codes. Usually stricter building codes result in higher quality buildings which might have a considerable cost advantage in maintenance cost or operating costs (e.g. better insulation = less energy costs). The quality of the building needs therefore included in the overall cost calculation.

Annualised furniture and fit-out costs are usually not considered as part of the office lease costs although the individual fit-out costs can be considerable, especially if short-term leases are considered (Axcell 2001). These costs need to be annualised and have an influence on the initial investment costs. The initial investment costs not only influence the depreciation charges but also the financing costs, based on the debt-to-equity ratio considered for the specific industry. 
These costs need to be included in the cost comparison to achieve a valid picture of the cost side for leased premises.

When calculating the transportation costs, a number of studies only consider the outbound quantity to be shipped. It is equally important to calculate the inbound shipping costs which can be substantial based on the position of the value chain the company is placed in. Again not considering this aspect puts the validity of the cost comparison into question. This is especially true for manufacturing industries which depend on raw material inputs.

Costs for natural gas and electricity costs should be considered in relation to the prevailing energy source $(s)$ in the country of destination. Where a country has sufficient and sustainable energy available, these costs tend to be lower than in countries typically dependent on energy imports. Good examples are Sweden or Canada which produce a large part of their electrical energy from hydropower resulting in considerable lower energy prices than for countries such Germany. As hydropower is a sustainable energy source, one might consider this as a lasting (positive) location-sensitive factor influencing the overall energy cost calculation.

Moreover some sub-groups are currently not included at all in standard cost comparison studies. Inclusion of these sub-groups offers considerable potential for improving the validity of the study results:

The validity of labor costs can be increased by including initial and further education costs for employees. These cost tend to vary significantly based on the national education systems, and even within nations. While Germany has a sophisticated system for dual education the majority of North American workers have to undergo a training-on-the-job, adding considerably to the labor costs, especially when setting-up a new operation.

Another area of concern in terms of validity is that no studies consider actual space utilisation patterns when calculating office and/or manufacturing space requirements. The space per worker requirements differ between countries resulting in different overall space requirements. This again influences the size of the land and the construction costs (for owned facilities) respectively and. the lease costs for offices (for leased facilities). Space utilization patterns therefore need to be an integral part of cost comparison studies.

Finally, most utility cost calculations do not pay attention to water and sewage costs which can again be a considerable part of the overall utility costs for manufacturing industries. In countries with a strict environmental regulatory framework, water tends to become a cost factor which outreaches energy costs. This is for example the case in Germany where water costs have risen considerably and sewage costs even exceed fresh water supply costs. When considering water and sewage costs not only consumption needs to be taken into account but also the degree of 
pollution as this largely influences the sewage prices. Valid cost comparison studies therefore need to take water and sewage costs into account too.

After having set-up the (improved) standard operating parameters, it is necessary to collect the relevant data for the location-sensitive factors identified. This step involves various challenges. First it needs to be ensured that the data is comparable over all locations included in the cost comparison study. This becomes evident when comparing major cost components such as labor costs or taxes which are based on fundamentally different systems in North America and Europe and even within Europe. Before collecting the relevant data, the systems need to be made comparable.

The more detailed the cost comparison study is in terms of locations analysed, the more a second area of concern becomes evident. That is data availability. While data on a national level is readily available in most cases, regional data availability is limited with even more restrictions on local data. Major cost drivers such a labor costs are often only available for larger cities putting the validity of the cost comparison studies involving smaller jurisdictions to a test. Generally, the smaller the jurisdictions, the more difficult it is to collect reliable key data.

Even if the comparability and availability of data has been ensured, care needs to be taken concerning the source of the data and the methodology applied. Different sources often produce inconsistent data for the same community, region or nation or even change the definition and methodology of data collection (Kotler, 1999) from one period to the other. Apart from frustration this can influence the validity of the data supplied.

After having finished the set-up of the standard operating parameters and the data collection for the selected location, it is then possible to produce the actual cost comparison study. This is done by 'multiplying' the operating parameters with the cost data, to produce a final cost ranking of the locations.

Care should be taken when interpreting the results of such studies as they often have a limited meaning to the individual project in question. This is especially true as the number of locations for comparison can usually not be selected by the site seeker, but depends on a pre-selection of cities done by the author of the cost comparison study. In addition, the selection of operating parameters can influence the outcome of the results, an issue already mentioned. Moreover the time dimension plays an important role because exchange rates, raw material price fluctuations etc. can considerably influence the outcome of the study. Finally, the extent of the comparison contributes to its validity. These four aspects should be analyzed more thoroughly in order to improve the validity (and possibly acceptance) of cost comparison studies. 


\section{The selection of comparable places}

Corporate site seekers usually start their location research by identifying a set of site selection factors important to their individual investment project as presented in Figures 2 and 3. Based on these site selection factors a number of locations are pre-selected which meet the project requirements. When proximity to customers is key, only locations within or close to metropolitan areas will be included in the shortlist. A labor cost priority will usually offer an opportunity for smaller and/or more remote locations to be shortlisted. These two examples clearly illustrate that it is difficult to foresee a typical set of locations which will have a chance to be included in the shortlist of most investment projects. Suppliers of cost comparison studies should pay attention to this fact as it can influence the acceptance of the studies by corporate site seekers.

When analysing cost comparison studies, a major shortcoming affecting the validity becomes evident: the limited number of locations included in the studies. All cost comparison studies available have pre-selected a limited number of locations for comparison, leaving no choice to the corporate site seeker to include his shortlisted locations in the cost comparison study - either the pre-selected locations match with the shortlisted locations or the study is of little value to the site seeker. This approach does not necessarily meet the real world of site selection.

When analysing the results of cost comparison studies, the corporate site seeker might wonder what Boston (USA), Kelowna (Canada) and Vienna (Austria) have in common. These cities might be presented as competitive alternatives from a cost point of view - having little in common as far industrial infrastructure, population patterns or even geographic location are concerned. The question might be raised whether it is admissible to compare locations featuring totally different characteristics or whether certain common criteria should be identified which allow for a valid comparison of locations.

\section{Some final thoughts: The question of sponsorship}

Why are certain locations pre-selected in cost comparison studies and others not? Cost comparison studies have increased the number of pre-selected locations over the years with up to 115 (KPMG, 2001) locations included in the most comprehensive studies currently available. However, this is still a relatively small number given the fact that on a global basis the figure of actual or would-be locations competing for a specific investment project exceeds 700,000 (Kotler, 1993). The question arises why these 115 locations have been chosen and especially how representative these locations are in terms of being a possible investment location.

When analysing the list of locations included in cost comparison studies and their overall cost ranking, one point becomes obvious: locations which have (co-)sponsored the development of individual cost comparison studies usually have a higher chance of being included in the studies. 
What is even more important is the fact that sponsoring locations show a much better overall cost ranking than cities and regions not contributing financially to the development and execution of the cost comparison study.

As part of the 2001 study of KPMG a cost ranking (lowest rating = lowest cost location) between European countries and Japan has been calculated comprising a total of 30 locations.

Interestingly, among the Top-10 cost competitive locations only two cities (20 per cent) could not be identified as study sponsors, among the Top-20 cost competitive locations only four cities (20 per cent) did not sponsor the study, while most of the least competitive cities did not contribute financially.

Studies of The Boyd Company have also been analysed in terms of sponsorship and study results. In all nine studies, the main study sponsor is presented as being the most cost competitive location.

Various conclusions can be drawn from these findings. While Canadian representatives believe that the study sponsorship of international investment development organisations "substantially added to the international credibility of its findings" (Meredith, 2000), the rationale of this argument is not explained further. It is noteworthy that Canada is presented as the most cost competitive country in the studies Canadian representatives are referring to. From a corporate site seekers point of view, the question might be raised why cities and regions - if they are actually the most cost competitive locations - need to spend money for sponsoring a study which is just confirming their cost competitiveness.

The answer to the question raised earlier might be that locations positively presented make it into cost comparisons studies because they just paid for that, while locations presented as less cost competitive locations were just included to let the sponsoring ones look better in terms of cost comparison. This will most likely not contribute to the overall validity and acceptance of such cost comparisons. Consequently an approach should be chosen where all locations presented contribute to the costs or even better to allow for no sponsoring stressing the independence of the results from any sponsorship. This will also permit for locations to be selected because they are representative rather than their ability to financially contribute to the development of the cost comparison study. 


\section{Author Biography}

Bjoern Jacobsen is a graduate in business administration from the University of Cooperative Education in Luebeck, Germany. After graduating he worked as the export sales manager of a German wholesale company in Denmark and The Netherlands. In 1991 he joined a German software company as an IT consultant followed by two years as a business support analyst for BP (British Petroleum) in Hamburg (Germany), Brussels (Belgium) and Hemel Hempstead (UK). In 1996 Bjoern joined the city development company of the Hanseatic City of Luebeck as a project manager for business cooperation. In 1998 he joined the newly formed Luebeck Business Development Corporation as a project manager for strategy and analysis. Since 2000 Bjoern is the Managing Principal of the Luebeck Business Development Corporation.

\section{References}

Adkison, Jeff. (2001, July). A wide-angle view of the location process. Area Development Magazine.

Area Development Magazine. (1986). Annual Corporate Survey 1986.

Area Development Magazine. (1990). Annual Corporate Survey 1990.

Area Development Magazine. (1995). Annual Corporate Survey 1995.

Area Development Magazine. (1999). Annual Corporate Survey 1999.

Area Development Magazine. (2000). Annual Corporate Survey 2000.

Axcell, Andrew, Procter, Andrew \& Fennel, Bill. (2001). The total office cost survey, City University Business School and Actium Consult: London.

Balderjahn, Ingo. (1995). Studies: Wirtschaftsstandort Brandenburg.

Deutsches Institut für Urbanistik. (1995). Rangfolge der Wichtigsten Standortfaktoren bei Unternehmensorientierten Dienstleistungen.

Deutsches Institut für Wirtschaftsforschung. (1995) Wie die Ostdeutsche Industrie Ihre Standortbedingungen Sieht.

Deutsches Institut für Wirtschaftsforschung. (2000). Standortbedingungen in Ostdeutschland Verbessert. 
Economist Intelligence Unit. (2001). Worldwide Business Cost Comparisons, London.

Ernst \& Young. (2001). European Investment Monitor Online 2001 Report, London.

European Business School. (2001). Standorte und Standortwahl bei Internet/e-commerce Gründungen in Deutschland, Oestrich-Winkel.

Forschungsstelle für empirische Sozialökonomik. (2002). Computeranalyse hilft bei der Standortsuche, Köln.

Gambale, Geraldine. (n.d). 15 ${ }^{\text {th }}$ Annual Corporate Survey, Area Development Online. Retrieved from http://www.area-development.com/past/1200/features/ covercontents.html.

Hahne, Ulf. (1995). Regionale Wirtschaftsförderung in der Praxis.

IMD. (2001). The World Competitiveness Yearbook.

Jones Lang Wotton. (1991). Immobilienstudie für Wien, 1991.

Kotler, Philip, Haider, Donald H. \& Rein, Irving. (1993). Marketing Places, New York.

Kotler, Philip, Asplund, Christer, Rein, Irving \& Haider, Donald H. (1999). Marketing Places Europe, London.

KPMG. (1999). The Competitive Alternatives: A Comparison of Business Costs in Major North American Cities. No. a.

KPMG. (1999) The Competitive Alternatives: A Comparison of Business Costs in North America and Europe / Focus on Quebec, No. b.

KPMG. (1999). The Competitive Alternatives: A Comparison of Business Costs in North America, Europe and Japan, No. c.

KPMG. (2001). The Competitive Alternatives: Comparing Business Costs in North America, Europe and Japan, G-7 2002 Edition.

Krieger, Winfried, \& von Stackelberg, Klaus. (1995) Standortwahlentscheidungen und Transportpreise in Fertigungsbetrieben peripherer Regionen. 
Levine, Andrew T. (1997). Getting inside the site selector's brain. Commentary, Fall edition.

Meredith, Greg. (2000). Canada's competitive edge: Defining a business image. (2000). The Economic and Technology Development Journal of Canada.

Musil, Thomas A. (2001). Impact analysis practices in economic development. Economic Development Review, Fall edition.

Pausenberger, Ehrenfried. (1994). Die Standortpolitik Internationaler Unternehmen.

Pittman, Robert, Denise, Julie \& Herron, Joan. (2001). Can a national data standard help economic development in your community? Economic Development Review, Fall edition.

Tillet, Chris. (1995). Real site location considerations.

UBS Switzerland. (2000). Prices and earnings around the globe.

Vause, Nicolas \& Hawksworth, John. (1999). Economic Geography of the New Europe, PriceWaterhouseCoopers, September.

Vitols, Sigurt. (2001). Unternehmensführung und arbeitsbeziehungen in deutschen tochtergesellschaften großer Ausländischer Unternehmen.

World Economic Forum. (2001). The global competitiveness report. 